\title{
Packaging Design for a Sustainable Community Business
}

\author{
Listia Natadjaja ${ }^{1 *}$, Laksmi Kusuma Wardani ${ }^{2}$, Diana Thamrin $^{2}$, and \\ Ronald Hasudungan Sitinjak ${ }^{2}$ \\ ${ }^{1}$ Department of Visual Communication Design, Petra Christian University, \\ Siwalankerto 121-131, Surabaya 60236, Indonesia. \\ ${ }^{2}$ Department of Interior Design, Petra Christian University, Siwalankerto 121-131 \\ Surabaya 60236, Indonesia
}

\begin{abstract}
The growth of the creative community cannot be quantitatively and qualitatively separated from the growing development of Creative Industry 4.0. Various creative communities produce a variety of creative products that are ready to be sold. Unfortunately, the focus of the community is often only on the product and not on the packaging design. Meanwhile, a product's packaging not only serves to protect the product but also to promote it and encourage purchase. The purpose of this research is to educate and help the community obtain packaging designs that are not only unique but also suitable for their products. By involving Packaging Design course students of the Visual Communication Design department, we attempted to assist a jewellery and accessories-making community as our research object. Students first attempted to deepen their clients' insights by conducting observations and in-depth interviews. In designing the packaging, they consulted with their tutors intensively. The packaging design that the students produced undergoes a selection process, which resulted in four packaging designs that were deemed fit for use. Two of the selected designs were registered to obtain IPRs in the Industrial Design category. Through this research, it is hoped that the packaging design produced by these students can be used to support the sale of community products. In addition to that, they can also be used to inspire other communities to acknowledge the role of packaging design as a means that can help the sustainability of their business.
\end{abstract}

Keywords: Community product, creative industry, industrial design, sustainability business, visual communication design.

\section{Introduction}

The qualitative and quantitative growth of the creative community cannot be separated from the growing development of the creative industry 4.0. Creative industry 4.0 has significantly changed the production process in many aspects such as design, workmanship, and service. The main objective of Industry 4.0 is to achieve efficiency and effectiveness through various means of operation and automation [1]. To face competition in this era, the Indonesian government has been trying to develop a creative economic sector that

\footnotetext{
*Corresponding author: listia@petra.ac.id
} 
intensifies information and creativity by relying on ideas and knowledge from human resources, where creativity and knowledge are the main assets in driving the economy. The Creative Economy Agency (Bekraft-Badan Ekonomi Kreatif) categorizes 16 creative industry subsectors including: application and development of games, architecture, product design, fashion, interior design, visual communication design, performance art, film, animation and video, photography, crafts, culinary, music, publishing, advertising, fine arts, television and radio [2]. The aim to increase the creative economy sector itself has been responded well with the emergence of various creative communities that can produce a variety of creative products that are ready to sell. Unfortunately, the community's focus is often only on the product and not on the packaging. Packaging design is an important aspect of product design because it not only serves to protect the product but can also help in its sales and promotion [3, 4]. In fact, packaging design can assist in the continuation of product sales in the market [4].

Starting with a research collaboration between the Interior Design study program and the Visual Communication Design study program at Petra Christian University, a team was created to help the community in terms of the interior styling for displaying products and also designing the packaging of the products sold. While the Interior Design students assist the communities in arranging the displays and interiors of their community spaces, the authors have observed another need of communities the created products to be sold. Of the many communities chosen as objects of study, there is one community engaged in art and craft that produces jewellery trinkets and various accessories. This research see the important role of the packaging design of these products that need to be a concern for the community, especially producers of the creative products. The purpose of this research is to educate and help the community to obtain packaging designs that are not only unique and innovative but also suitable for their products.

\section{Method}

By involving students in the Packaging Design course at the Visual Communication Design study program, we try to help communities working in the field of art and craft. Their products include jewellery products (brooches, earrings, necklaces) and accessories (key chains, bags, adult shoes, baby shoes, bags, wallets, scarves, various knit products, and other handicraft products). Seventeen students were involved in the design process which was divided into eight groups. Each group was accompanied by a tutor. For their assignment, students worked in groups, each group amount of two to three persons. Students attempted to understand their client's (community) insight by conducting observations and in-depth interviews. This research is a qualitative study in which data collection was more directed to multiple methods through observation and interviews. Students also made observations by analysing the products sold, displays used and also the interaction of clients with their customers. Observations in field research will usually provide more accurate knowledge than asking informants about them [5, 6]. In this study besides observation, students conducted interviews. Interviews in qualitative research are more oriented towards directed conversations [5] in which researchers ask questions and listen to answers from informants and try to uncover their meaning [7]. Interviews can also be done to validate observations. In social research, it is better not only to use one method but to add another method. The use of multiple methods will enrich data collection [8].

\section{Design for a sustainable business}

A good business is a business that is long-lasting or sustainable. Sustainability is a new approach in business to create long-lasting values by considering the environmental, social 
and economic aspects so that a company can survive in the future. [9] The next issue to be considered is "What is the role of designers with their designs so that a business can be sustainable?" A designer is morally and ethically responsible for the design and its impact that they make, and one task that could be done by a good designer is to implement the concept of sustainable development in the design [10,11]. A sustainable business, of course, will consider sustainable packaging design to protect and display its products. A package is called sustainable if it is designed with regard to the environment. This can be done in various ways, including: using recycled or easily recycled materials, minimizing the production process by not using excess energy that pollutes the environment and designing in such a way that it can be reused so that it extends the life of the packaging itself. In addition to considering environmental factors, packaging design must pay attention to economic and social factors [12].

In the process of making packaging designs for this community, the designers have paid attention to the sustainable factor of packaging, although not completely. Firstly, the material used was an un-laminated paper. Secondly, the production process was exclusive, meaning that it was not mass-made. Making the package depends on the needs of the number of products to be packaged. Thirdly, all forms of packaging were made to be reusable, both for storing the same item or storing other goods. The form of the packaging was made unique, beautiful and sturdy so as to give a preventive sense of being thrown away after use. With the creation of a sustainable packaging design where storage and usage of packaging can last for a long time, it is hoped that consumers would always remember the product brand and the products that are packaged, so as to benefit the sustainability of the business community.

\section{Packaging design process}

The process of making packaging designs was carried out as effectively as possible by first exploring the client's data, in this case, the community. In designing the packaging, the students also consulted with their tutors intensively. They must go through several steps in the process of packaging design as follows:

i. Students get a brief from the Packaging Design course lecturer.

ii. Students visited the exhibition of interior design styling assisted by interior design students, which at that time also displayed products sold by the community.

iii. Students made observations to choose further the products they will design. The products chosen by students included: women's shoes, baby shoes, cloth purses, knit wallets, brooches, key chains, and stone jewellery.

iv. Students conducted in-depth interviews with community leaders and members about the community and the products produced.

v. Students confirmed and explored information about their product choices to clients and tutors.

vi. Students made several alternative packaging designs.

vii. Students presented alternative packaging designs to get input from all tutors.

viii. Students consulted with their tutors.

ix. Students made final designs

$\mathrm{x}$. Students documented packaging in accordance with the requirements for submitting industrial design Intellectual Property Rights (IPR).

xi. Students whose designs were selected for registration by IPR made revisions.

\subsection{Important steps}

From the many steps of making the packaging design, we tried to summarize the process into two important steps in making this packaging design that is, how to obtain data as an input. To understand the community's needs, students must observe them in order to choose 
a suitable product to be used as the object for packaging design. After that, students explored client briefs through in-depth interviews. Client brief in the world of advertising is the amount of data provided by clients, in this case, advertisers, and the data are used as a basis for promotion or to advertise themselves [13]. In this activity, students needed a client brief to discover the background of the client, the vision and mission of the community, the activities carried out, the characteristics of the product produced, what kind of packaging design do they need, and the target market they are aiming for. Product marketing will influence the packaging design made, and hence, the client must have certain boundaries that determine which community groups are eligible to be their consumers [14].

After obtaining a client brief, students then made a creative brief. Creative briefs are generated after getting a clear client brief that is obtained through observations, interviews and various discussions between clients and students as designers [13]. With the creative brief, students created design concepts and produced alternative designs that were presented to the packaging design lecturer who also acts as their tutor. In this design process, the creative briefs made by students were only presented to tutors due to time constraints. The role of tutors is very important in the teaching and learning process as they help lecturers improve the quality and competency of learning by mentoring, monitoring, and more specifically, to achieve learning objectives [15]. After getting input related to the design elements such as material selection, color, typography, illustration, information, size, and packaging pattern, the students made revisions, and produced the final design.

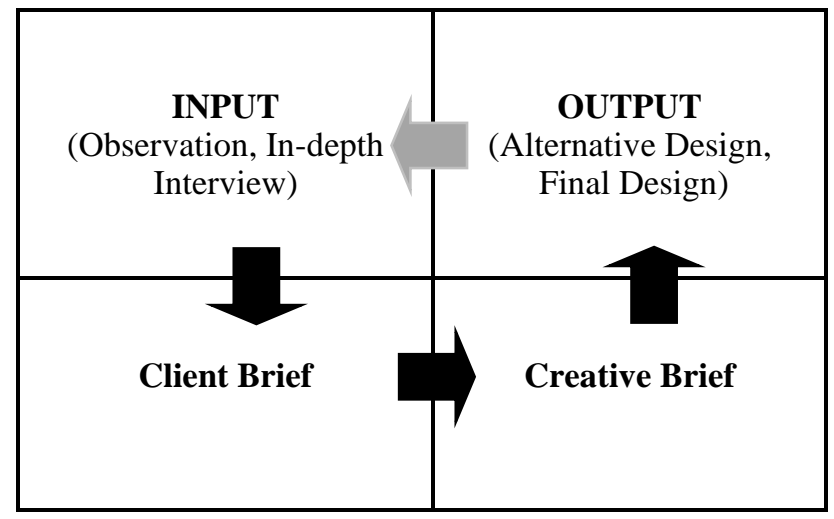

Fig. 1. Important steps in packaging design.

\subsection{Selected packaging design}

The packaging design produced by 17 students divided into eight groups was subsequently selected. The selection process resulted in four packaging designs that were deemed fit for use, and two of them were registered to obtain IPR for industrial design.

From the four selected packaging designs, researchers asked the students to revise their designs again. However, only two students, in this point, met the criteria to be registered for obtaining an IPR certificate in industrial design, namely Cabochon boxes and Coin Pouch. The implemented criteria were as follows: originality, uniqueness, an innovation that differs from other packaging designs, made from recyclable materials, simple manufacturing process, can be hand-made easily, neatness, can be reused, and was sturdy enough to be stored in the long run. 

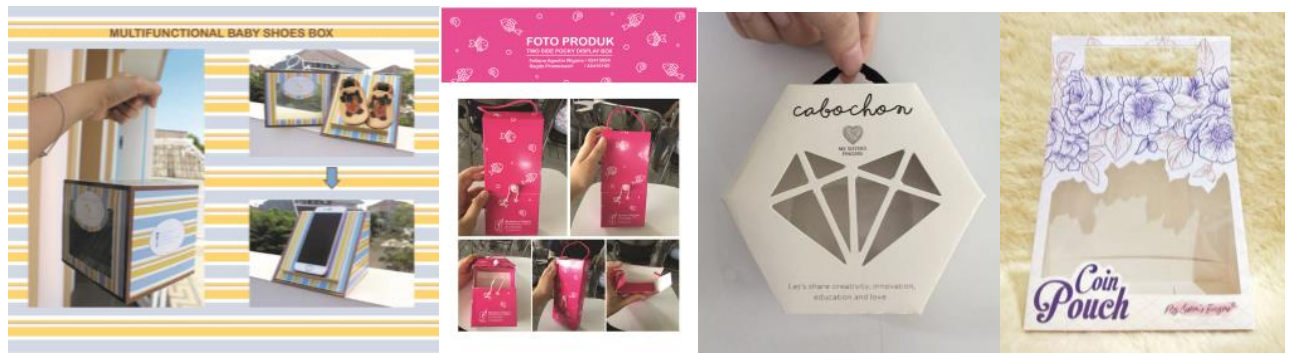

Fig. 2. Four selected packaging design.

*(left to right) Baby shoes boxes by Monica Christie, and Angeline Mandagi, Pocky Display Boxes by Feliana Agustin and Regita Prameswari, Cabochon Boxes by Bella Cornelia and Bella Viencencia, Coin Pouch by Jessica and Sharleen Sutjitra.

\section{Conclusion}

Many important factors must be considered in designing product packaging, one of which is how packaging design can assist in making the business last for a long time. The business of a community is usually not a mass product but is a special product in which only one or two products are often produced. Likewise, in designing a packaging design for exclusive products, designers are not required to think about the mass production of the packaging they make. However, after all the packaging designs have been produced, apart from its beauty, it should also be easy to be handmade. Hence, both the product and the packaging can have an exclusive, unique and innovative design that makes it different from the mass products sold in the market.

The contribution to green design in this project is how a package is designed with regard to the client's needs while also displaying a consideration of its impact on the environment. The use of recyclable materials such as paper with exclusive packaging does not burden the client in having to keep the packaging in an excess amount, and hence, they do not need to spend large funds for producing it economically. Producing a packaging that can be repeated or stored longer also displays environmental considerations as it does not create too much packaging waste.

After the IPR certificate is issued, the packaging design will be given to the community for use. Through this research, it is hoped that the packaging design produced by the students can be used to assist the community in selling their products. Hopefully, it can also be used to inspire other communities to acknowledge the role of packaging design as a tool that can benefit the sustainability of their business.

\section{Acknowledgement}

Authors would like to thank the Directorate General of Research, Technology, and Higher Education Indonesia for providing the PTUPT research grant in funding this research [No. 229/SP2H/LT/DRPM/2019]. Authors would also like to thank the Packaging Design teaching team Ms. Elisabeth Christine Yuwono who assisted in accompanying the students as they conducted a field survey and guiding the packaging design process. Thank you also for Packaging Design students in the year 2017 class for their kindly cooperation and effort. Lastly, the authors thank the community who have collaborated with us in this research.

\section{References}

1. Slusarczyk, Pol. J. Manag. Stud., 17,1:232-248(2018). https://yadda.icm.edu.pl/baztech/element/bwmeta1.element.baztech-a5b275da-808e$\underline{44 \mathrm{~d} 0-9599-004 \mathrm{~d} 03 \mathrm{a} 80 \mathrm{a} 08}$ 
2. Syahid, Ada 16 subsektor ekonomi kreatif, apa sajakah itu? [Online] from https://elshinta.com/news/154365/2018/08/30/ada-16-subsektor-ekonomi-kreatif-apasajakah-itu (2018) [Accessed on 10 September 2019]. [in Bahasa Indonesia].

3. I. Wirya. Kemasan yang menjual: menang bersaing melalui kemasan. [Packaging that sells: wins competing through packaging] Gramedia Pustaka Utama, Jakarta (1999).

[in Bahasa Indonesia].

https://books.google.co.id/books/about/Kemasan_yang_menjual.html?id=by3sNwAA $\underline{\text { CAAJ }}$

4. M.R. Klimchuck, S.A. Krasovec. Packaging Design: Succesfull Product Branding from Concept to Sell. New Jersey: John Wileys \& Son (2012). https://books.google.co.id/books?id=kbp_SBXFeBEC\&dq0

5. S. Kvale. Interview Views: An Introduction to Qualitative Research Interviewing. Thousand Oaks, CA: Sage Publications (1996). https://books.google.co.id/books?id=3 3NxwEACAAJ

6. C.A.B. Waren. Qualitative Interviewing In: Handbook of Interview Research. Thousand Oaks, CA: Sage Publications (2011). https://methods.sagepub.com/book/handbook-of-interview-research-2e

7. H.J. Rubin and I.S. Rubin. Qualitative Interviewing: The Art of Hearing Data. 2nd Edition. London: Sage Publications (2011) https://books.google.co.id/books?hl=en\&lr=\&id=bgekGK xpYsC

8. R. Kumar. Research Methodology: Step-by-step guide for beginners. Los Angles: Sage (2019). https://books.google.co.id/books?id=J2J7DwAAQBAJ0

9. K. Haanaes. Why all businesses should embrace sustainability. [Online] from https://www.imd.org/research-knowledge/articles/why-all-businesses-should-embracesustainability/ (2016) [Accessed on 10 September 2019].

10. O. Diegel, Journal of Sustainable Development, 3,3:68-75(2010). http://156.62.60.45/handle/10292/1713

11. D. Nemerson, J. Rosenbeck, A designer's role in sustainability the extent to which product and process designers can play a role in environmental sustainability and social responsibility. [Online] from https://www.idsa.org/sites/default/files/Nemerson.pdf (n.d), p. 1-9. [Accessed on 10 September 2019]

12. P. Forbes. The role of sustainable packaging in 2019 [+ examples]. [Online] from https://packhelp.com/sustainable-packaging/ (2019). [Accessed on 11 September 2019]

13. Zorraquino. What is the client brief?[Online] from https://www.zorraquino.com/en/ dictionary/digital-marketing/what-is-briefing.html (2002). [Accessed on 11 September 2019].

14. D. Kasilo, Komunikasi Cinta: Menembus G-Spot Konsumen Indonesia. [Love Communication: Penetrating the Indonesian Consumer G-Spot]. Jakarta: KPG (2008). [in Bahasa Indonesia]. https://books.google.co.id/books?hl=en\&lr=\&id=u3C7IXCLRR4C

15. N.R. Morillas, M.F. Garrido, Revista Internacional de Organizaciones, 12:89100(2014). https://dialnet.unirioja.es/descarga/articulo/4994821.pdf 